\title{
ALLOGRAFT PROCUREMENT, PROCESSING AND TRANSPLANTATION
}

\author{
A Comprehensive Guide for Tissue Banks
}


This page intentionally left blank 


\section{ALLOGRAFT PROCUREMENT, PROCESSING AND TRANSPLANTATION}

A Comprehensive Guide for Tissue Banks

\section{Aziz Nather}

National University of Singapore, Singapore

\section{Norimah Yusof}

Malaysian Nuclear Agency, Malaysia

\section{Nazly Hilmy}

BATAN Research Tissue Bank, Indonesia 
Published by

World Scientific Publishing Co. Pte. Ltd.

5 Toh Tuck Link, Singapore 596224

USA office: 27 Warren Street, Suite 401-402, Hackensack, NJ 07601

UK office: 57 Shelton Street, Covent Garden, London WC2H 9HE

\section{British Library Cataloguing-in-Publication Data}

A catalogue record for this book is available from the British Library.

\section{ALLOGRAFT PROCUREMENT, PROCESSING AND TRANSPLANTATION A Comprehensive Guide for Tissue Banks \\ Copyright (c) 2010 by World Scientific Publishing Co. Pte. Ltd. \\ All rights reserved. This book, or parts thereof, may not be reproduced in any form or by any means, electronic or mechanical, including photocopying, recording or any information storage and retrieval system now known or to be invented, without written permission from the Publisher.}

For photocopying of material in this volume, please pay a copying fee through the Copyright Clearance Center, Inc., 222 Rosewood Drive, Danvers, MA 01923, USA. In this case permission to photocopy is not required from the publisher.

ISBN-13 978-981-4291-18-7

ISBN-10 981-4291-18-8

Typeset by Stallion Press

Email: enquiries@stallionpress.com

Printed in Singapore. 
This book is dedicated to Professor Glyn Owen Phillips, Technical Advisor to DDG, IAEA (Mr Qian) for his vision and mission to development of tissue banking (RAS 7/008) in the Asia-Pacific region (1985 to 2008) and to the development and success of IAEA/NUS Diploma Course and IAEA/NUS Training Centre in Singapore for training tissue bank operators (since November 1997).

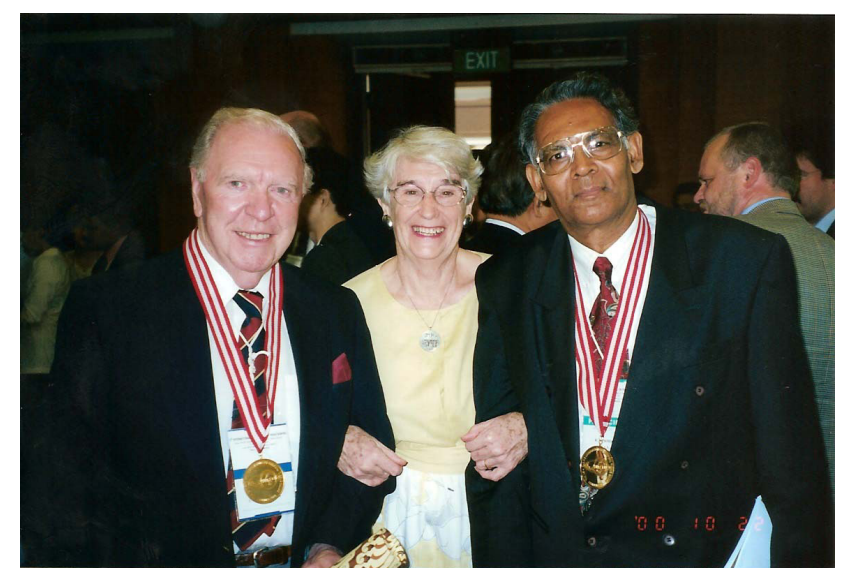

Professor Phillips (left), Mrs. Rhiain Phillips (center) and Mr. Ramen Mukherjee (Technical Officer for RAS 7/008: right)

Professor Phillips and Mr. Mukheerjee received Honorary Membership of APASTB during the 8th Scientific Conference of Asia Pacific Association of Surgical Tissue Banking (APASTB) in Bali, 2000. 
This page intentionally left blank 


\section{Contents}

Dedication $\quad \mathrm{v}$

Preface $\quad$ xi

About the Editors $\quad$ xiii

List of Contributors $\quad \mathrm{xV}$

Part I: History 1

Chapter 1 Evolution of Allograft Transplantation 3

Aziz Nather and Shushan Zheng

Chapter 2 Tissue Banking in the Asia-Pacific Region: 29

Current Trends and Future Directions Aziz Nather, Yi Lin Sim and Shushan Zheng

Chapter 3 Asia Pacific Association of Surgical Tissue

Banks - Past, Present and Future Aziz Nather, Zameer Aziz and Shushan Zheng

Chapter 4 Distance Learning Diploma Course for Training Tissue Bank Operators - 12 Years of Experience by IAEA/NUS Training Centre Aziz Nather, Poh Lin Chan and Shushan Zheng

Part II: Organisation Systems

Chapter 5 Manpower Organisation

Poh Lin Chan and Aziz Nather 
Chapter 6 Design of Tissue Banks Aziz Nather and Poh Lin Chan

Chapter 7 Equipments and Facilities in Tissue Banks Poh Lin Chan and Aziz Nather

Chapter 8 Setting Up a Tissue Bank

Aziz Nather and Poh Lin Chan

Part III: Rules and Regulations

Chapter 9 Ethical, Religious, Legal and Cultural Issues

for Tissue Banking Aziz Nather, Jia Ming Low and Yi Lin Sim

Chapter 10 Ensuring Safety - Donor Evaluation and Screening Aziz Nather and Shushan Zheng

\section{Part IV: Basic Sciences}

Chapter 11 Anatomy of Musculoskeletal System Aziz Nather, Zameer Aziz and Cui Lian Chong

Chapter 12 Biology of Healing of Bone Allografts Aziz Nather and Yan Yi Han

Chapter 13 Biomechanics of Healing of Bone Allografts Aziz Nather, Si Qi Koh and Wen Hui Teng

Chapter 14 Basic Principles of Transplantation Immunology Aziz Nather and Shushan Zheng

Chapter 15 Principles of Sterile Techniques Siti Zubaidah Mordiffi, Mary Tan and Aziz Nather

Chapter 16 Preparation of Tissue Grafts during Transplantation Aziz Nather and Choon Wei Lee

Chapter 17 Transmissible Diseases 
Part V: Procurement $\quad 291$

Chapter 18 Bone Procurement: Living Donors 293 Aziz Nather and Cui Lian Chong

Chapter 19 Bone Procurement: Deceased Donors Aziz Nather and Cui Lian Chong

Chapter 20 Amnion Procurement Aziz Nather and Cui Lian Chong

Chapter 21 Skin Procurement and Processing

Aziz Nather, Cui Lian Chong and Xin Bei Chan

\section{Part VI: Processing}

Chapter 22 Processing of Bone and Musculoskeletal Soft Tissue Allografts Aziz Nather and Li Min Tay

Chapter 23 Amnion Processing Hasim Mohamad

\section{Part VII: Radiation Sciences}

Chapter 24 Principle Concepts of Radiation Sterilisation for Tissue Allografts Norimah Yusof and Nazly Hilmy

Chapter 25 Good Radiation Practices for Sterilisation of Allografts Norimah Yusof and Noriah Mod Ali

Chapter 26 Establishing Radiation Dose for Sterilisation of Tissue Allografts: $25 \mathrm{kGy}$ and Lower Norimah Yusof and Nazly Hilmy

Chapter 27 Bioburden Estimation in Tissue Banking Norimah Yusof, Asnah Hassan and Nazly Hilmy

Chapter 28 Elimination of Viruses, Prion and Emerging 
Chapter 29 Interaction of Radiation with Tissues Norimah Yusof and Awang Hazmi Awang Junaidi

Chapter 30 Effects of Gamma Irradiation on the Biomechanics 467 of Bone

Aziz Nather, Ahmad Hafiz Zulkify and Shu Hui Neo

\section{Part VIII: Clinical Application}

Chapter 31 Environmental Management: Control and Safety Nazly Hilmy and Norimah Yusof

Chapter 32 Clinical Applications of Bone Allografts Aziz Nather, Zameer Aziz and Jia Ming Low

Chapter 33 Clinical Applications of Irradiated Amnion Grafts 501 Menkher Manjas, Petrus Tarusaraya and Nazly Hilmy

Chapter 34 Clinical Applications of Radiation-Sterilised Grafts in Periodontal Surgery Retno Dwijartini Tantin, Paramita Pandansari, Basril Abbas and Nazly Hilmy

Chapter 35 Complications of Bone Allografts Aziz Nather and Li Min Tay

Chapter 36 Allograft Engineering Aziz Nather and Yan Yi Han

Index 


\section{Preface}

Singapore has been actively involved with the International Atomic Energy Agency (IAEA) in training tissue bank operators from the AsiaPacific region, Latin America, Eastern Europe and Africa, since NUH Tissue Bank was appointed to be the IAEA/NUS Regional Training Centre for RCA member states (Asia Pacific) in 1997. In November 1997, NUS held the first IAEA/NUS Diploma Course in Tissue Banking, the first of its kind in the world. Since then, ten batches have successfully participated - the 11th batch, at the time of writing, has started as an online diploma course in August 2009. The course has been conducted as an online course since 2004 (starting from the 6th batch). To date a total of 141 tissue bank operators (from 27 countries in the Asia-Pacific region, Latin America, Eastern Europe, Africa and Australia) have convocated with an NUS Diploma in Tissue Banking.

Singapore has been instrumental in development of the IAEA/NUS Multi-Media Curriculum on Tissue Banking, which was produced in April 1998. This curriculum served as the textbook for all diploma courses run by IAEA jointly with NUS. This curriculum was translated into Spanish and used as textbook for all IAEA courses held in Latin America, with Argentina as the Regional Training Centre since 2000. It has also been translated into Korean language in 2003 by IAEA for use in its Korean National Training Courses run annually since 2004.

This book is the latest update on all topics in the previous MultiMedia Curriculum ranging from donor selection criteria, procurement techniques, laboratory testing, processing techniques for deep-frozen and 
freeze-dried allografts, quality control issues, radiation sterilization techniques, clinical transplantation of bones and soft tissues and principles of sterile techniques in the operating room. Incorporated in the book are the basic science topics such as anatomy, biomechanics, microbiology, and immunology.

This book will be useful for all tissue bank operators, doctors, nurses, technicians and allied healthcare professionals dealing with the practice of tissue procurement, processing and clinical transplantation.

\author{
Aziz Nather \\ Editor \\ Director, National University Hospital Tissue Bank \\ Director, IAEA/NUS International Training Centre \\ for Tissue Bank Operators (Singapore) \\ Director, IAEA/NUS Diploma Course in \\ Tissue Banking (Singapore) \\ Senior Consultant \\ Department of Orthopaedic Surgery \\ Yong Loo Lin School of Medicine \\ National University of Singapore
}




\section{About the Editors}

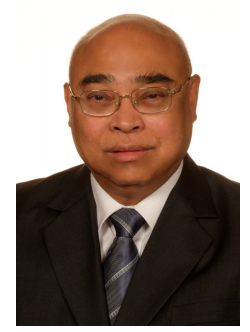

Associate Professor Abdul Aziz Nather

Director, National University Hospital Tissue Bank

Director, IAEA/NUS Training Centre for Tissue Bank Operators

Director, IAEA/NUS Diploma Course in Tissue Banking

Senior Consultant, Department of Orthopaedic Surgery

Yong Loo Lin School of Medicine

National University of Singapore

Singapore

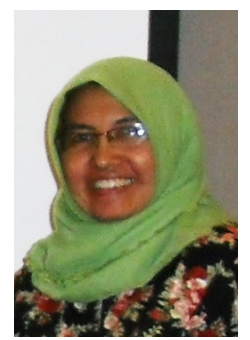

Dr Norimah Yusof

Head, Malaysian Nuclear Agency Research Tissue Bank

Radiation Biologist

Director, Division of Agriculture and Biosciences

Head, Division of Biological Applications

Malaysian Nuclear Agency

Bangi, Selangor, Malaysia 


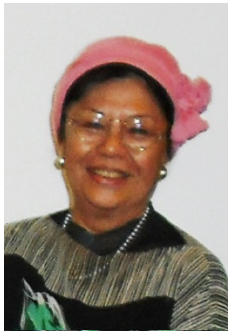

\section{Dr Nazly Hilmy}

Senior Consultant

BATAN Research Tissue Bank (BRTB)

Radiation Biologist

Center for Research and Development of Isotopes and Radiation Technology

BATAN, Jakarta, Indonesia 


\title{
List of Contributors
}

\author{
Basril Abbas \\ BATAN Research Tissue Bank (BRTB)
}

Center for the Application of Isotopes and Radiation Technology

BATAN, Jakarta 12070

Indonesia

Noriah Mod Ali

Malaysian Nuclear Agency (NM)

Bangi 43000 Kajang, Selangor

Malaysia

Zameer Aziz

NUH Tissue Bank

Department of Orthopaedic Surgery

Yong Loo Lin School of Medicine

National University of Singapore

Singapore

Chan Poh Lin

NUH Tissue Bank

Department of Orthopaedic Surgery

Yong Loo Lin School of Medicine

National University of Singapore

Singapore 


\section{Chan Xin Bei}

NUH Tissue Bank

Department of Orthopaedic Surgery

Yong Loo Lin School of Medicine

National University of Singapore

Singapore

\section{Chong Cui Lian}

NUH Tissue Bank

Department of Orthopaedic Surgery

Yong Loo Lin School of Medicine

National University of Singapore

Singapore

Han Yan Yi

NUH Tissue Bank

Department of Orthopaedic Surgery

Yong Loo Lin School of Medicine

National University of Singapore

Singapore

Asnah Hassan

Malaysian Nuclear Agency (NM)

Bangi 43000 Kajang, Selangor

Malaysia

Nazly Hilmy

BATAN Research Tissue Bank (BRTB)

Center for the Application of Isotopes and Radiation Technology

BATAN, Jakarta 12070

Indonesia

Awang Hazmi Awang Junaidi

Faculty of Veterinary Medicine

Universiti Putra Malaysia

43400 UPM Serdang, Selangor

Malaysia 
Koh Si Qi

NUH Tissue Bank

Department of Orthopaedic Surgery

Yong Loo Lin School of Medicine

National University of Singapore

Singapore

Lee Choon Wei

NUH Tissue Bank

Department of Orthopaedic Surgery

Yong Loo Lin School of Medicine

National University of Singapore

Singapore

Low Jia Ming

NUH Tissue Bank

Department of Orthopaedic Surgery

Yong Loo Lin School of Medicine

National University of Singapore

Singapore

Menkher Manjas

Dr. M. Djamil Hospital Tissue Bank

Department of Surgery

Faculty of Medicine

Andalas University

Padang, Indonesia

Hasim Mohamad

School of Medical Science,

University of Science, Malaysia

Department of Surgery,

Hospital Raja Perempuan Zainab II

Kota Bharu, Malaysia 
Siti Zubaidah Mordiffi

Evidence Based Nursing Unit

Nursing Department

National University Hospital

Singapore

Aziz Nather

NUH Tissue Bank

IAEA/NUS Training Centre for Tissue Bank Operators (Singapore)

Department of Orthopaedic Surgery

Yong Loo Lin School of Medicine

National University of Singapore

Singapore

Neo Shu Hui

NUH Tissue Bank

Department of Orthopaedic Surgery

Yong Loo Lin School of Medicine

National University of Singapore

Singapore

Paramita Pandansari

BATAN Research Tissue Bank (BRTB)

Center for the Application of Isotopes and Radiation Technology

BATAN, Jakarta 12070

Indonesia

Sim Yi Lin

NUH Tissue Bank

Department of Orthopaedic Surgery

Yong Loo Lin School of Medicine

National University of Singapore

Singapore 
Mary Tan

Nursing Education Unit

Nursing Department

National University Hospital

Singapore

Retno Dwijartini Tantin

BATAN Dental Clinic

Center for Technology of Radiation Safety and Metrology

BATAN, Jakarta 12440

Indonesia

Tay Li Min

NUH Tissue Bank

Department of Orthopaedic Surgery

Yong Loo Lin School of Medicine

National University of Singapore

Singapore

Petrus Tarusaraya

Sitinala Leprosy Hospital

Tangerang, Indonesia

Teng Wen Hui

NUH Tissue Bank

Department of Orthopaedic Surgery

Yong Loo Lin School of Medicine

National University of Singapore

Singapore

Norimah Yusof

Malaysian Nuclear Agency (NM)

Bangi 43000 Kajang, Selangor

Malaysia 


\title{
Zheng Shushan
}

NUH Tissue Bank

Department of Orthopaedic Surgery

Yong Loo Lin School of Medicine

National University of Singapore

\section{Singapore}

\author{
Ahmad Hafiz Zulkify \\ Department of Orthopaedics, Traumatology and Rehabilitation \\ Kulliyah of Medicine \\ International Islamic University Malaysia \\ Malaysia
}

